passado, quando a populaçáo mundial era relativamente pequena e os recursos naturais aparentemente infinitos, praticamente náo havia consideraçáo do impacto tecnológico sobre o ambiente. Agora que a população mundial exerce forte pressão sobre o planeta, o desenvolvimento tecnológico deve ser direcionado para a utilizaçáo de recursos renováveis e para a preservação da integridade ecológica do ambiente. A consideração de tais critérios requererá maior conhecimento básico dos sistemas ecológicos e mais, náo menos, desenvolvimento tecnológico. Também vai requerer a estabilização da população mundial em um nível sustentável. Felizmente, a humanidade está apta a atingir tais objetivos; de outra forma, estaremos destinados a um baixo nível evolutivo entre as inteligências que possivelmente permeiam o universo.

\title{
DinÂMica NÃo-LinEAR, Sistemas CAÓtICOS E APLICAÇÕES
}

\author{
JACOB PALIS \\ (Instituto de Matemática Pura e Aplicada \\ CNPq, Rio de Janeiro, Brasil)
}

$\bigvee_{\text {cessos iterativos expressos em termos matemáticos por (iteraçóes }}^{\text {uitos dos fenômenos da natureza podem ser modelados por pro- }}$ de) uma transformaçáo em certo espaço de eventos, representando o caso de evolução temporal discreta ou o caso de uma evoluçáo contínua por uma equação diferencial ou um campo de vetores. Em ambas as situaçóes, processos iterativos são chamados sistemas dinâmicos. Considera-se que esse campo teve início com o grande matemático francês Henri Poincaré, há cerca de 100 anos. Mas sua origem está claramente vinculada à Mecânica Celeste e, nesse sentido, podemos mencionar Newton, Galileu e muitos outros como pioneiros.

Dentre muitas outras aplicações, tais modelos são empregados na previsão de eventos, seja a curto, seja a longo prazo. Assim, está-se freqüentemente interessado no comportamento a longo prazo das solu- 
ções, isto é, no futuro das trajetórias da transformação ou da equação diferencial. Isso leva à noção de atratores: eles são o conjunto de eventos limitantes que exibem a gama de possibilidades para o comportamento futuro das trajetórias iniciadas em diferentes pontos do espaço de eventos. A situaçâo mais simples corresponde a um atrator que consiste de um ponto fixo, o qual é robusto sob perturbaçóes pequenas dos coeficientes da transformação original, ou da equação diferencial original. É como certos modelos clássicos em Economia, que levam a pontos ótimos de equilíbrio robusto. Consideraçóes semelhantes aplicam-se aos atratores pontuais periódicos, nos quais a órbita de atração é periódica, com período dado. Atratores ainda mais complicados, mesmo que muito estruturados e robustos, foram estudados nos anos sessenta.

Com o grande desenvolvimento das técnicas computacionais, esses modelos revelaram riqueza muito maior $e$, na verdade, inesperado grau de incerteza quanto ao comportamento das soluçóes a longo prazo! Os novos atratores, descobertos nas décadas de 70 e 80, receberam o nome de estranhos: a incerteza quanto ao comportamento futuro de suas trajetórias e suas forma e robustez sáo muito mais sutis. Ainda assim, parecem ser muito comuns em sistemas náo-lineares. Note que estamos falando de sistemas determinísticos, algumas vezes representados por equaçóes muito simples, como polinomiais quadráticas ou de segundo grau, tais como as que, na verdade, a biologia usa como modelo simples para crescimento de populaçóes. Novamente, não estamos introduzindo qualquer incerteza nas equaçôes do sistema, como na Mecânica Quântica e, apesar disso, as soluçōes têm um grau intrínseco de incerteza: não se trata de ruídos ou limitaçōes dos experimentos.

As implicaçóes sáo imensas, tanto do ponto de vista matemático como da perspectiva que podemos obter dos fenômenos assim modelados e, até mesmo, a uma postura filosófica nas Ciências. As aplicações são abundantes em Biologia, Física, Engenharia, Economia etc. 